\title{
SEQUENCE DETERMINING OF CONSTRUCTION OF THE OFFSHORE WIND FARM CONSTRUCTION APPLYING PERMUTATION METHOD
}

\section{Vygantas Bagočius, Edmundas Kazimieras Zavadskas, Zenonas Turskis}

\section{Introduction}

The world oil crisis of the seventies has lead to important changes regarding energy resources and their exploitation. In the nineties, there was an increased focus on reducing the negative effects that the massive and uncontrolled use of the fossil fuels had on the environment. The beginning of the 21st century brought along new technologies in the green energy [29].

In recently have been recognized the value of wind power as a major renewable energy source for long term; because wind is free, clean and renewable [27].

Wind power one is the most deserving of all cleaner energy production options from technical, environmental, socio-economical and sociopolitical standpoint (geothermal, solar, tidal, biomass, hydro) for more widespread deployment [20].

The wind energy is one of the most widely exploited and rapidly evolved types of renewable energy [26].

The World Wind Energy Association (WWEA), claims that a capacity of the wind energy reaching a total value of $1900 \mathrm{GW}$ is likely before the year 2020. China, USA, Germany, Spain, India and other countries, especially Eastern Europe, as well as many Asian countries and Latin America are expected to demonstrate a significant growth in this market [28].

Europe is the absolute leader in building the offshore wind turbines. One of the key reasons for building the offshore wind turbines is a lack of territory, suitable for the onshore stations.
This situation is highly relevant in densely populated countries, such as Germany, Denmark, and Netherlands.

Report of The Wind Energy European Association, on the European level, generated a more detailed estimate for the year 2020 [21]:

- 230 GW of installed capacity (190 GW onshore, $40 \mathrm{GW}$ offshore);

- Annual investments of 23.5 billion EUR (14.7 billion EUR onshore, 8.8 billion EUR offshore);

- Generation of 582 TWh of electric energy (433 TWh onshore, 148 TWh offshore);

- $14-17 \%$ of the entire EU energy request shall be generated by the wind energy production;

- Reduction of $\mathrm{CO}_{2}$ emission by $333 \times 10^{6}$ tons annually.

European Wind Energy Association estimated that in 2030 the offshore wind turbines will generate more energy compared to the onshore wind turbines.

Lithuania, being a member of the EU, should execute its assumed obligations related to this field. It is anticipated that in 2020 the wind turbines may produce 10 percent of all the electric power consumed in Lithuania. This means that the country should establish favorable conditions to build the wind turbines with a total power of $500 \mathrm{MW}$ [11].

Onshore wind energy technology is more mature than offshore, but nowadays, there is a considerable trend to the establishment of offshore wind farms [26]. Offshore wind power as an upcoming technology and growing business to deliver renewable energy with no 
greenhouse gas emissions and without depleting fossil energy resources has startling perspectives for developers, authorities and society [2].

Wind energy is clean and inexpensive, but space for the turbines is becoming scarce, which makes offshore wind an attractive choice. Therefore, offshore wind power has recently been widely focused on and developed, as it is reliable, intensive, and its source is abundant and offers vast offshore areas. It can not only ease reliance on oil and cut down emissions, but also stimulate the marine economy development and offer job opportunities [10].

Offshore wind farms present higher investment, operational and maintenance cost, the significant offshore wind resource potential, the higher quality wind resources located at sea, the ability to use even larger wind turbines due to avoidance of certain land and the ability of construction of even larger power plants than onshore, as there is no geographical "limit", form the primary motivations of developing offshore wind energy [26].

Development of such farms is highly promising for the distressed coastal regions, with the fishery businesses and shipbuilding companies closing down. In order to select a suitable offshore territory for construction of the wind turbines, the entire marine area should be mapped out in detail.

The offshore wind energy farms compared to the onshore wind farms have advantages [13] as follows:

- Wind is stronger and steady, thus energy content is greater by $40 \%$;

- Invisible from the shore, thus no issues of visual or noise-related disturbances;

- Territorial restrictions may be avoided;

- Greater power generation;

- Better connection of electrical network;

- Lower wind turbulence means lower depreciation of installations and almost maintenance-free operation.

There exists main negative aspects for the offshore wind turbines:

- Higher project implementation costs;

- More expensive substructure (groundwork);

- Adverse weather conditions obstruct construction works;

- Limited industrial experience;

- Higher requirements for corrosion resistant materials, i.e. exposure to salt, water, and air;
Safety and effect issues on flora and fauna as well as natural habitats.

\section{Selection Criteria for Wind Farm Locations}

The offshore wind turbines opened new possibilities for service and public utility service sectors as well as a labor market. Problem of selection construction for sites wind farms is both economic, technical and management problem.

Good location's selection leads to success of wind farms construction. There are three key factors influencing the location of wind farms as follows: wind energy output, grid availability and construction conditions [15].

Having completed a thorough collection of data, entire information is processed in order to select a potential and appropriate location for the wind farms - a multiple criteria analysis is conducted.

The choice of energy generation is multicriteria decision-making process made up of a number of aspects at different levels [3].

In order to analyze potential locations for construction of the wind turbines, it is necessary to gather and process the data, defining very detailed features and parameters of a specific location intended for construction. These data can be divided into two main categories [14]:

- Information on the restricted areas within the region of interest;

- Information on the relevant characteristics in the region of interest.

The first group is includes all the exceptions that occur in the marine area being studied, either natural or human imposed, that restrict the use of a particular region. These areas are used to define exclusion areas, and as a consequence are not used in the analysis [14]:

- Harbour entrances and navigation routes;

- Areas with environmental restrictions;

- Oil and gas extraction;

- Military exercise areas;

- Underwater cables;

- Sand and gravel extraction;

- Marine archaeology sites;

- Landscape and seascape as public heritage.

The second group determines all the technical constraints that will allow evaluating 
the locations regarding its suitability for the deployment of wind and wave energy conversion systems [14]:

- Water depth;

- Distance to shore;

- Wind energy resource;

- Investment costs;

- Energy production capacity;

- Realization time;

- $\mathrm{CO}_{2}$ emissions avoided;

- Acoustic noise;

- Social acceptability;

- Seabed Geology;

- Safety;

- Area of the territory;

- Max power on the area;

- Other.

\section{Application of Permutation Method for Multi-Criteria Analysis}

To solve the problem was selected the permutation method. The permutation method uses Jaquet-Lagreze's feasible permutations of all possible rankings and alternatives [6]. When applying this method all permutations of alternatives according to their preferability are checked and compared among themselves [30]. This method allows dealing with quantitative data as well as with data expressed in words (lexicographic defined data) and enables us define the most appropriate ordering of alternatives. The method was developed by Paelinck [16].

Suppose a number of alternatives $\left(a_{i}, i=1,2, \ldots, m\right)$ have to be evaluated according to attributes $\left(x_{j}, j=1,2, \ldots, n\right)$. Decision making matrix is a set up according to the form [24]:

$$
P=\frac{a_{1}}{\vdots}\left[\begin{array}{ccc}
x_{11} & \cdots & x_{1 n} \\
\vdots & \ddots & \vdots \\
x_{m 1} & \cdots & x_{m n}
\end{array}\right]
$$

For a solution of problems there exists an obligatory set of criteria weight coefficients $w_{j}$ :

$$
w_{j}=1,2, \ldots, n, \quad \sum_{j=1}^{n} w_{j}=1 .
$$

The aim is to choose the most appropriate alternative from the $\mathrm{m}$ feasible alternatives. That is, one must assign the preferability relationship on the set of alternatives, or what is same, find the rearrangement of alternatives which fit best the system of values [30].

Let us assume there exists 3 feasible. Then there exist $m !=3 \times 2 \times 1=6$ permutations [30]:

$\pi_{1}=a_{1} \succ a_{2} \succ a_{3} ; \pi_{2}=a_{1} \succ a_{3} \succ a_{2} ; \pi_{3}=a_{2} \succ a_{1} \succ a_{3} ;$

$\pi_{4}=a_{2} \succ a_{3} \succ a_{1} ; \pi_{5}=a_{3} \succ a_{1} \succ a_{2} ; \pi_{6}=a_{3} \succ a_{2} \succ a_{1}$.

In case of the checked order of alternatives is $\pi_{2}$ there could to be stated concordance partial order is: $\left\{a_{1} \leq a_{3} ; a_{1} \leq a_{2} ; a_{3} \leq a_{2}\right\}$, and the set of discordance partial order is: $\left\{a_{1} \leq a_{3} ; a_{1} \leq a_{2} ; a_{3} \leq a_{2}\right\}$.

If in ranking (permutation) of alternatives the partial ranking $a_{k}>a_{l}$ appears, it means that $x_{k j} \geq x_{l j}$ will be rated $w_{j}$ and $x_{k h} \leq x_{l h}$ will be rated $\left(-w_{h}\right)$.

The ranking of alternatives $\beta_{g}(g=1,2, \ldots, m !)$ is carried out as described above.

Let us suppose that there is $g^{\text {th }}$ permutation: $\pi_{g}=\left\{\cdots, a_{k}, \cdots, a_{l}, \cdots\right\} g=1,2, \cdots, m !$, where $a_{k}$ is preferable to $a_{l}$. Then to this permutation there is given following evaluation criterion $\beta_{g}$ :

$$
\begin{gathered}
\beta_{g}=\sum_{k, l=1}^{m} \sum_{j \in C_{k l}} w_{j}-\sum_{k, l=1, k \neq l}^{m} \sum_{j \in C_{k l}} w_{j} ; \\
(g=1,2, \cdots, m !)
\end{gathered}
$$

where,

$$
\begin{aligned}
& C_{k l}=\left\{j \mid x_{k j} \geq x_{l j}\right\}, k, l=1,2, \ldots, m ; k \neq l ; \\
& H_{k l}=\left\{j \mid x_{k j} \prec x_{e j}\right\}, k, \quad l=1,2, \ldots, m ; k \neq l .
\end{aligned}
$$

The best concordant ordering is the one which value $\beta_{g}$ is the largest.

The permutation method requires weights of criteria. For this purpose there was selected AHP (Analytic Hierarchy Process) method. AHP [19] is one of the most popular multicriteria decision-making models. AHP involves quantification based on comparative and relative evaluation. It is one of the most widely used methods to determine criteria weights. All the AHP calculations and evaluations were carried out using a software, MakeltRational [7].

AHP method was suggested by Saaty [18] in 1980. Saaty established 9 objects as the upper limit of his integer scale for multiple pair wise comparisons [25]. Generally we can represent the comparative importance scale of criteria as shown in Table 1. 
Tab. 1: Comparative importance scale of critetia

\begin{tabular}{l|l} 
Intensity of importance & Definition \\
\hline 1 & Criteria $i$ and $j$ have equal importance \\
\hline 3 & Criterion $i$ is moderately more important than criterion $j$ \\
\hline 5 & Criterion $i$ is strongly more important than criterion $j$ \\
\hline 7 & Criterion $i$ is very strongly or demonstrably more important than criterion $j$ \\
\hline 9 & Criterion $i$ is extremely more important than criterion $j$ \\
\hline $2,4,6,8$ & Compromise values between the two adjacent judgments \\
\hline Reciprocals & $\begin{array}{l}\text { If activity } i \text { has one of the nonzero numbers assigned to it when compared with activity } j, \\
\text { nonzero }\end{array}$
\end{tabular}

Source: own

The AHP method is based on the pair-wise comparison matrix. Experts compare all the evaluation criteria:

$$
\begin{gathered}
A=\left[\begin{array}{cccccc}
a_{11} & a_{12} & \cdots & a_{1 j} & \cdots & a_{1 n} \\
\vdots & \vdots & & \vdots & & \vdots \\
a_{i 1} & a_{i 2} & \cdots & a_{i j} & \cdots & a_{1 n} \\
\vdots & \vdots & & \vdots & & \vdots \\
a_{n 1} & a_{n 2} & \cdots & a_{n j} & \cdots & a_{n n}
\end{array}\right], \\
a_{i j}=w_{i} / w_{j}, i, j=1,2, \ldots, n
\end{gathered}
$$

Thus, when the matrix $A$ is multiplied by the vector formed by each weighting $w=\left(w_{1}, w_{2}, \ldots\right.$, $\left.w_{n}\right)^{T}$, one gets:

$A w=\left[\begin{array}{cccccc}\frac{w_{1}}{w_{1}} & \frac{w_{1}}{w_{2}} & \cdots & \frac{w_{1}}{w_{j}} & \cdots & \frac{w_{1}}{w_{n}} \\ \vdots & \vdots & & \vdots & & \vdots \\ \frac{w_{i}}{w_{1}} & \frac{w_{i}}{w_{2}} & \cdots & \frac{w_{i}}{w_{j}} & \cdots & \frac{w_{i}}{w_{n}} \\ \vdots & \vdots & & \vdots & & \vdots \\ \frac{w_{n}}{w_{1}} & \frac{w_{n}}{w_{2}} & \cdots & \frac{w_{n}}{w_{j}} & \cdots & \frac{w_{n}}{w_{n}}\end{array}\right] \cdot\left[\begin{array}{c}w_{1} \\ \vdots \\ w_{j} \\ \vdots \\ w_{n}\end{array}\right]=\left[\begin{array}{c}w_{1}^{\prime} \\ \vdots \\ w_{j}^{\prime} \\ \vdots \\ w_{n}^{\prime}\end{array}\right]$ (6)
In the AHP the pair-wise comparisons in a judgment matrix are considered to be adequately consistent if the corresponding consistency ratio $(C R)$ is less than $10 \%$ [18]. First the consistency index $(\mathrm{Cl})$ needs to be estimated. This is done by adding the columns in the judgment matrix and multiply the resulting vector by the vector of priorities (i.e. the approximated eigenvector) obtained earlier. This yields an approximation of the maximum eigenvalue, denoted by $\lambda_{\text {max }}$ [23]:

$$
\lambda_{\max }=\frac{1}{n}\left(\frac{w_{1}^{\prime}}{w_{1}}+\frac{w_{2}^{\prime}}{w}+\ldots+\frac{w_{n}^{\prime}}{w_{n}}\right)
$$

By this method, one can obtain the characteristic vector, referred to as the priority vector. Besides this Saaty suggested the consistency index C.I $=\left(\lambda_{\max }-n\right) /(n-1)$. Next the consistency ratio $C . R$ is obtained by dividing the $C . I$ value by the Random Consistency index (R.I): C.R=C.I/R.I. R.I as values given in table 2 .

\section{Tab. 2: $\quad \boldsymbol{R} I$ values for different values of $\boldsymbol{n}$}

\begin{tabular}{l|c|c|c|c|c|c|c|c|c|c|c|c}
$n$ & 1 & 2 & 3 & 4 & 5 & 6 & 7 & 8 & 9 & 10 & 11 & 12 \\
\hline$R I$ & 0 & 0 & 0.58 & 0.90 & 1.12 & 1.24 & 1.32 & 1.41 & 1.45 & 1.49 & 1.51 & 1.48 \\
\hline
\end{tabular}




\section{Case study}

With the issues arising due to a limited use of the land, noise generated by the wind turbines or other issues and seeking to use the entire wind potential of the Baltic Sea, an option of the offshore wind farms is highly appreciated.

At present tame there is no built offshore wind farms in Lithuania. The international project "Development Prospects of Offshore Wind Energy in Marine Areas of Lithuania, Poland and Russia (POWER)", was identified in 2008 the marine area and an exclusive economic zone of Lithuania a potential region for construction of the wind farms [22].

It is stated that waters belonging to the Republic of Lithuania may shelter five wind farms. The main objective of the task is to establish a sequence for the wind turbine construction, a total power of which would approximately reach up to 1065 MW. Fig.1 presents a preliminary layout of the wind farms [5].

\section{Fig. 1: Preliminary layout of the wind farms}

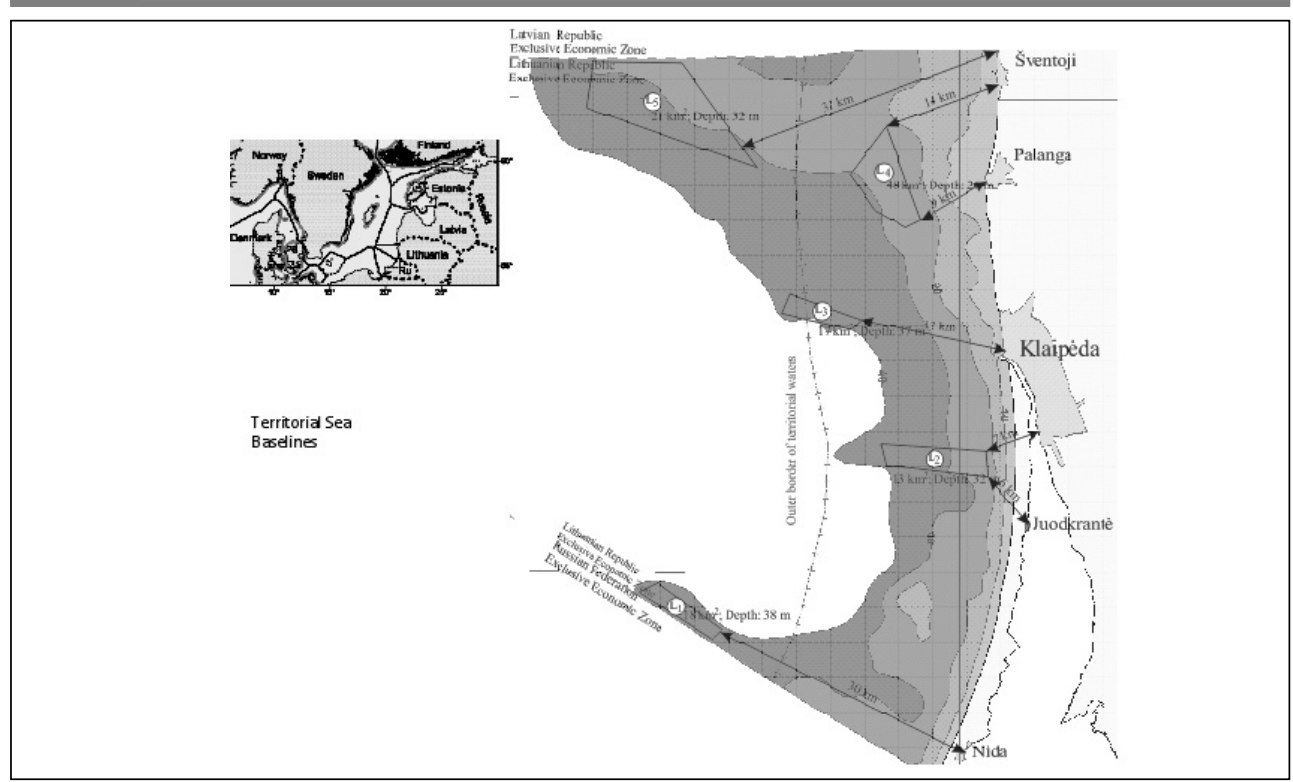

Source: The model for economical feasibility study of offshore wind power parks [22]

The key criteria were selected for multicriteria analysis:

- $\mathrm{x}_{1}$ - area of the territory $\left(\mathrm{km}^{2}\right)$ - Area covered by the wind farms.

- $x_{2}$ - water depth $(m)$ - The water depth at the site is a very strong technical limitation and site evaluation. Within the technically admissible range typically the shallower the water depth the most suitable the location, as it usually means reduced construction costs [14].

- $x_{3}$ - distance to shore $(\mathrm{km})$ - The distance to shore is measured in straight line, as it is meant to evaluate the cost of the submarine cable that connects to land [14].
- $\mathrm{x}_{4}$ - average wind velocity $(\mathrm{m} / \mathrm{s})$ - For offshore wind systems this parameter is essential for the evaluation of the sites. Wind velocity is determined by performing annual wind parameters' measurements (averaging of observation data of the closest meteorological station) [12].

- $\mathrm{x}_{5}$ - max power on the area (103 MW) The power plants park may be constructed very widely or vice versa. Each separate wind power plant has an operation area it needs. This way we may assess the power plants on a certain area [1].

- $\mathrm{x}_{6}$ - amount of energy per year (MWh) How much energy the wind power plants farm produces in fact [1]. 


\section{Business Administration and Management}

- $x_{7}$ - investments (106 €) - Construction, electrical connection, grid connection, planning, wind turbines, approvals, utilities and management are the main components of capital cost for wind farm projects [9].

- $x_{8}-\mathrm{CO}_{2}\left(10^{3} t\right)$ - this is one of the most important criterion why a wind power plants park is constructed. It is very important in construction of wind power plants. It differs in each country [1].

The initial criteria for evaluation of alternatives are given in Table 1 [17].

\section{Tab. 3: Initial decision-making matrix}

\begin{tabular}{c|c|c|c|c|c|c|c}
\multirow{2}{*}{ Optimum } & \multirow{2}{*}{ Criteria } & \multicolumn{5}{|c|}{ Alternatives } & Weights \\
\cline { 3 - 8 } & & $\mathrm{L}_{1}$ & $\mathrm{~L}_{2}$ & $\mathrm{~L}_{3}$ & $\mathrm{~L}_{4}$ & $\mathrm{~L}_{5}$ & $\mathbf{w}_{\mathbf{i}}$ \\
\hline $\max$ & $\mathrm{x}_{1}$ & 18 & 33 & 17 & 48 & 121 & 0.098 \\
\hline $\min$ & $\mathrm{x}_{2}$ & 38 & 32 & 37 & 26 & 32 & 0.103 \\
\hline $\min$ & $\mathrm{x}_{3}$ & 52 & 20 & 16,5 & 11,8 & 31 & 0.074 \\
\hline $\max$ & $\mathrm{x}_{4}$ & 9.50 & 8.41 & 8.90 & 8.1 & 9.60 & 0.088 \\
\hline $\max$ & $\mathrm{x}_{5}$ & 80 & 150 & 75 & 215 & 545 & 0.118 \\
\hline $\max$ & $\mathrm{x}_{6}$ & 327.7 & 519.3 & 282.5 & 703.8 & 2262.2 & 0.211 \\
\hline $\min$ & $\mathrm{x}_{7}$ & 290.4 & 348.5 & 192.6 & 457.3 & 1160.3 & 0.246 \\
\hline $\min$ & $\mathrm{x}_{8}$ & 205.1 & 325.1 & 176.8 & 440.6 & 1416.1 & 0.062 \\
\hline
\end{tabular}

Source: own

The criteria weights were determined by the AHP method based on the answers of 11 experts. According to the data obtained from the interview in Table 3, one can construct the matrix $A$ and further calculate the weight of every criteria, the maximum eigenvalue $\left(\lambda_{\text {max }}\right)$, the consistency index (C.I) and the consistency rate $(C . R)$ as follows. An examples show for one expert:

$$
\left.\begin{array}{c}
A w=\left[\begin{array}{cccccccc}
1 & 1 & 2 & 2 & 1 / 3 & 1 / 3 & 1 / 5 & 1 / 5 \\
1 & 1 & 1 & 1 & 1 / 2 & 1 / 5 & 1 / 5 & 3 \\
1 / 2 & 1 & 1 & 1 / 2 & 1 / 2 & 1 / 3 & 1 / 4 & 2 \\
1 / 2 & 1 & 2 & 1 & 1 & 1 / 4 & 1 / 4 & 3 \\
3 & 2 & 2 & 1 & 1 & 1 / 2 & 1 / 2 & 4 \\
3 & 5 & 3 & 4 & 2 & 1 & 1 & 3 \\
5 & 5 & 4 & 4 & 2 & 1 & 1 & 7 \\
1 / 2 & 1 / 3 & 1 / 2 & 1 / 3 & 1 / 4 & 1 / 3 & 1 / 7 & 1
\end{array}\right] \cdot\left[\begin{array}{l}
0.081 \\
0.070 \\
0.062 \\
0.081 \\
0.136 \\
0.239 \\
0.294 \\
0.037
\end{array}\right]=\left[\begin{array}{l}
0.694 \\
0.579 \\
0.508 \\
0.695 \\
1.137 \\
2.019 \\
2.388 \\
0.314
\end{array}\right] \\
\lambda_{\max }=\frac{1}{8}\left(\frac{0.694}{0.081}+\frac{0.579}{0.070}+\frac{0.508}{0.062}+\frac{0.695}{0.081}+\frac{1.137}{0.136}+\frac{2.019}{0.239}+\frac{2.388}{0.294}+\frac{0.314}{0.037}\right.
\end{array}\right)=8.387
$$


Based on 11 expert answers criteria weights were determined as follows: $w_{1}=0.098$, $\mathrm{w}_{2}=0.103, \mathrm{w}_{3}=0.074, \mathrm{w}_{4}=0.088, \mathrm{w}_{5}=0.118$, $w_{6}=0.211, w_{7}=0.246, w_{8}=0.062$.

The establishment of preferences of alternatives according to the set of quantitative and qualitative criteria was performed using the method of permutations [4], [8], [30], [31].

At five feasible alternatives of wind farms there can be $5 !=5 \times 4 \times 3 \times 2 \times 1=120$ permutations. The calculation process shortly is presented in Table 4.

\section{Tab. 4: Feasible permutations and calculation process of evaluation criterion (part 1)}

\begin{tabular}{|c|c|c|c|c|c|}
\hline & \multicolumn{5}{|c|}{$\pi_{1}=\mathrm{L}_{1}>\mathrm{L}_{2}>\mathrm{L}_{3}>\mathrm{L}_{4}>\mathrm{L}_{5}$} \\
\hline & $\mathrm{L}_{1}$ & $\mathrm{~L}_{2}$ & $\mathrm{~L}_{3}$ & $\mathrm{~L}_{4}$ & $\mathrm{~L}_{5}$ \\
\hline $\mathrm{L}_{1}$ & 0 & $\begin{array}{l}0.088+0.246+ \\
+0.062=0.396\end{array}$ & $\begin{array}{l}0.098+0.088+ \\
+0.118+0.211= \\
=0.515\end{array}$ & $\begin{array}{l}0.088+0.246+ \\
+0.062=0.396\end{array}$ & $\begin{array}{l}0.246+0.062= \\
=0.308\end{array}$ \\
\hline $\mathrm{L}_{2}$ & $\begin{array}{l}0.098+0.103+ \\
+0.074+0.118+ \\
+0.211=0.604 \\
\end{array}$ & 0 & $\begin{array}{l}0.098+0.103+ \\
+0.118+0.211= \\
=0.530\end{array}$ & $\begin{array}{l}0.088+0.246+ \\
+0.062=0.396\end{array}$ & $\begin{array}{l}0.074+0.246+ \\
+0.062=0.382\end{array}$ \\
\hline $\mathrm{L}_{3}$ & $\begin{array}{l}0.103+0.074+ \\
+0.246+0.062= \\
=0.485\end{array}$ & $\begin{array}{l}0.074+0.088+ \\
+0.246+0.062= \\
=0.470\end{array}$ & 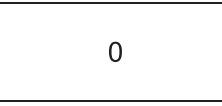 & $\begin{array}{l}0.088+0.246+ \\
+0.062=0.396\end{array}$ & $\begin{array}{l}0.074+0.246+ \\
+0.062=0.382\end{array}$ \\
\hline $\mathrm{L}_{4}$ & $\begin{array}{l}0.098+0.103+ \\
+0.074+0.118+ \\
+0.211=0.604\end{array}$ & $\begin{array}{l}0.098+0.103+ \\
+0.074+0.118+ \\
+0.211=0.604\end{array}$ & $\begin{array}{l}0.098+0.103+ \\
+0.074+0.118+ \\
+0.211=0.604\end{array}$ & 0 & $\begin{array}{l}0.103+0.074+ \\
+0.246+0.062= \\
=0.485\end{array}$ \\
\hline $\mathrm{L}_{5}$ & $\begin{array}{l}0.098+0.103+ \\
+0.074+0.088+ \\
+0.118+0.211= \\
=0.692\end{array}$ & $\begin{array}{l}0.098+0.088+ \\
+0.118+0.211= \\
=0.515\end{array}$ & $\begin{array}{l}0.098+0.103+ \\
+0.088+0.118+ \\
+0.211=0.618\end{array}$ & $\begin{array}{l}0.098+0.088+ \\
+0.118+0.211= \\
=0.515\end{array}$ & 0 \\
\hline \multicolumn{2}{|c|}{ Evaluation criterion $\beta_{1}$} & \multicolumn{2}{|c|}{ Concordance values } & \multicolumn{2}{|c|}{ Non-concordance values } \\
\hline & $6-5.711=-1.525$ & $\begin{array}{l}0.396+0.515+0.3 \\
0.396+0.382+0.3 \\
=4.186\end{array}$ & $\begin{array}{l}96+0.308+0.530+ \\
96+0.382+0.485= \\
\end{array}$ & $\begin{array}{l}0.604+0.485+0 . \\
+0.604+0.692+0 \\
=5.711\end{array}$ & $\begin{array}{l}+0.604+0.604+ \\
5+0.618+0.515=\end{array}$ \\
\hline & \multicolumn{5}{|c|}{$\Pi_{2}=L_{1}>L_{2}>L_{3}>L_{5}>L_{4}$} \\
\hline & $L_{1}$ & $\mathrm{~L}_{2}$ & $\mathrm{~L}_{3}$ & $\mathrm{~L}_{5}$ & $\mathrm{~L}_{4}$ \\
\hline $\mathrm{L}_{1}$ & 0 & $\begin{array}{l}0.088+0.246+ \\
+0.062=0.396\end{array}$ & $\begin{array}{l}0.098+0.088+ \\
+0.118+0.211= \\
=0.515\end{array}$ & $\begin{array}{l}0.246+0.062= \\
=0.308\end{array}$ & $\begin{array}{l}0.088+0.246+ \\
+0.062=0.396\end{array}$ \\
\hline $\mathrm{L}_{2}$ & $\begin{array}{l}0.098+0.103+ \\
+0.074+0.118+ \\
+0.211=0.604\end{array}$ & 0 & $\begin{array}{l}0.098+0.103+ \\
+0.118+0.211= \\
=0.530\end{array}$ & $\begin{array}{l}0.074+0.246+ \\
+0.062=0.382\end{array}$ & $\begin{array}{l}0.088+0.246+ \\
+0.062=0.396\end{array}$ \\
\hline $\mathrm{L}_{3}$ & $\begin{array}{l}0.103+0.074+ \\
+0.246+0.062= \\
=0.485\end{array}$ & $\begin{array}{l}0.074+0.088+ \\
+0.246+0.062= \\
=0.470\end{array}$ & 0.000 & $\begin{array}{l}0.074+0.246+ \\
+0.062=0.382\end{array}$ & $\begin{array}{l}0.088+0.246+ \\
+0.062=0.396\end{array}$ \\
\hline $\mathrm{L}_{5}$ & $\begin{array}{l}0.098+0.103+ \\
+0.074+0.088+ \\
+0.118+0.211= \\
=0.692\end{array}$ & $\begin{array}{l}0.098+0.088+ \\
+0.118+0.211= \\
=0.515\end{array}$ & $\begin{array}{l}0.098+0.103+ \\
+0.088+0.118+ \\
+0.211=0.618\end{array}$ & 0 & $\begin{array}{l}0.098+0.088+ \\
+0.118+0.211= \\
=0.515\end{array}$ \\
\hline $\mathrm{L}_{4}$ & $\begin{array}{l}0.098+0.103+ \\
+0.074+0.118+ \\
+0.211=0.604\end{array}$ & $\begin{array}{l}0.098+0.103+ \\
+0.074+0.118+ \\
+0.211=0.604\end{array}$ & $\begin{array}{l}0.098+0.103+ \\
+0.074+0.118+ \\
+0.211=0.604\end{array}$ & $\begin{array}{l}0.103+0.074+ \\
+0.246+0.062= \\
=0.485\end{array}$ & 0 \\
\hline \multicolumn{2}{|c|}{ Evaluation criterion $\beta_{2}$} & \multicolumn{2}{|c|}{ Concordance values } & \multicolumn{2}{|c|}{ Non-concordance values } \\
\hline \multicolumn{2}{|c|}{$4.216-5.681=-1.465$} & \multicolumn{2}{|c|}{$\begin{array}{l}0.396+0.515+0.308+0.396+0.530+ \\
0.382+0.396+0.382+0.396+0.515= \\
=4.216\end{array}$} & \multicolumn{2}{|c|}{$\begin{array}{l}0.604+0.485+0.470+0.692+0.515+ \\
+0.618+0.604+0.604+0.604+0.485= \\
=5.681\end{array}$} \\
\hline
\end{tabular}


Tab. 4: Feasible permutations and calculation process of evaluation criterion (part 2)

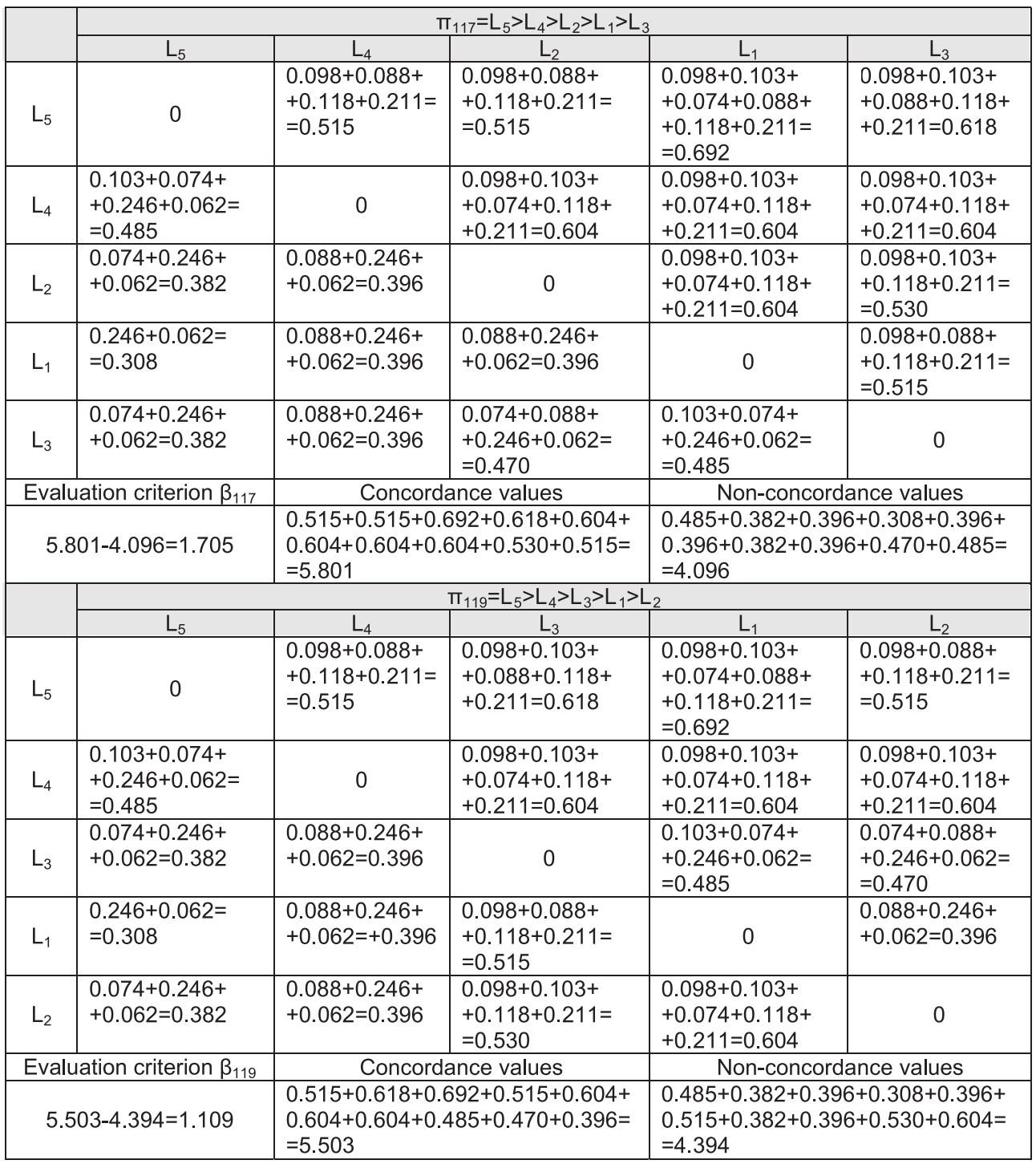




\section{Tab. 4: Feasible permutations and calculation process of evaluation criterion (part 3)}

\begin{tabular}{|c|c|c|c|c|c|}
\hline & \multicolumn{5}{|c|}{$\Pi_{120}=L_{5}>L_{4}>L_{3}>L_{2}>L_{1}$} \\
\hline & $\mathrm{L}_{5}$ & $\mathrm{~L}_{4}$ & $\mathrm{~L}_{3}$ & $\mathrm{~L}_{2}$ & $\mathrm{~L}_{1}$ \\
\hline $\mathrm{L}_{5}$ & 0 & $\begin{array}{l}0.098+0.088+ \\
+0.118+0.211= \\
=0.515\end{array}$ & $\begin{array}{l}0.098+0.103+ \\
+0.088+0.118+ \\
+0.211=0.618\end{array}$ & $\begin{array}{l}0.098+0.088+ \\
+0.118+0.211= \\
=0.515\end{array}$ & $\begin{array}{l}0.098+0.103+ \\
+0.074+0.088+ \\
+0.118+0.211= \\
=0.692\end{array}$ \\
\hline $\mathrm{L}_{4}$ & $\begin{array}{l}0.103+0.074+ \\
+0.246+0.062= \\
=0.485\end{array}$ & 0 & $\begin{array}{l}0.098+0.103+ \\
+0.074+0.118+ \\
+0.211=0.604\end{array}$ & $\begin{array}{l}0.098+0.103+ \\
+0.074+0.118+ \\
+0.211=0.604\end{array}$ & $\begin{array}{l}0.098+0.103+ \\
+0.074+0.118+ \\
+0.211=0.604\end{array}$ \\
\hline $\mathrm{L}_{3}$ & $\begin{array}{l}0.074+0.246+ \\
+0.062=0.382\end{array}$ & $\begin{array}{l}0.088+0.246+ \\
+0.062=0.396\end{array}$ & 0 & $\begin{array}{l}0.074+0.088+ \\
+0.246+0.062= \\
=0.470\end{array}$ & $\begin{array}{l}0.103+0.074+ \\
+0.246+0.062= \\
=0.485\end{array}$ \\
\hline $\mathrm{L}_{2}$ & $\begin{array}{l}0.074+0.246+ \\
+0.062=0.382\end{array}$ & $\begin{array}{l}0.088+0.246+ \\
+0.062=0.396\end{array}$ & $\begin{array}{l}0.098+0.103+ \\
+0.118+0.211= \\
=0.530\end{array}$ & - & $\begin{array}{l}0.098+0.103+ \\
+0.074+0.118+ \\
+0.211=0.604\end{array}$ \\
\hline $\mathrm{L}_{1}$ & $\begin{array}{l}0.246+0.062= \\
=0.308\end{array}$ & $\begin{array}{l}0.088+0.246+ \\
+0.062=0.396\end{array}$ & $\begin{array}{l}0.098+0.088+ \\
+0.118+0.211= \\
=0.515\end{array}$ & $\begin{array}{l}0.088+0.246+ \\
+0.062=0.396\end{array}$ & 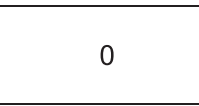 \\
\hline \multicolumn{2}{|c|}{ Evaluation criterion $\beta_{120}$} & \multicolumn{2}{|c|}{ Concordance values } & \multicolumn{2}{|c|}{ Non-concordance values } \\
\hline \multicolumn{2}{|c|}{$5.711-4.186=1.525$} & \multicolumn{2}{|c|}{$\begin{array}{l}0.515+0.618+0.515+0.692+0.604+ \\
0.604+0.604+0.470+0.485+0.604= \\
=5.711\end{array}$} & \multicolumn{2}{|c|}{$\begin{array}{l}0.485+0.382+0.396+0.382+0.396+ \\
0.530+0.308+0.396+0.515+0.396= \\
=4.186\end{array}$} \\
\hline
\end{tabular}

Source: own

The value $\beta_{117}=1.705$ is the largest. Hence, the permutation should be regarded as the most rational and on its base a series of wind turbine park alternatives according to their preferences should be constructed.

\section{Conclusions}

During the last past years, the wind energy has become a widely used source of energy seeking to maximize a use of renewable energy sources compared to fossil fuel or nuclear energy. For this reason, the wind farms is a highly relevant issue, which should be analyzed in-depth in order to prosper with technologically and economically effective production of the wind energy without harming the environment and wellbeing of the society.

Executing obligations to the European Union Lithuania has been highly interested and focused on renewable energy sources and wind energy in particular. Seeking a greater and more effective use of the wind turbines, it was determined that an option of building the wind farms in the Baltic Sea does really exist. Considering the experience of other countries, the offshore wind turbines feature a great potential.
The marine area, belonging to Lithuania, might potentially shelter five wind farms, a total power of which might approximately reach 1065 MW.

Calculations were made in order to estimate the best sequence for the wind turbine construction related process. Having the key criteria identified (investments, amount of energy per year, max power on the area, water depth, area of the territory, average wind velocity, distance to shore, $\mathrm{CO}_{2}$ ) and using the permutation method, a construction sequence for the wind farms in the Baltic Sea, close to the costal lines of Lithuania, has been established $-\left\{\mathrm{L}_{117}\right\}=\left\{\mathrm{L}_{4}>\mathrm{L}_{5}>\mathrm{L}_{2}>\mathrm{L}_{3}>\mathrm{L}_{1}\right\}$.

Having all of the possible wind farms built over the years, Lithuania would not only execute its obligations to the European Union, but would also contribute to building its energy diversification.

\section{References}

[1] BAGOČIUS, V., ZAVADSKAS, E.K., TURSKIS, Z. Multi-person selection of the best wind turbine based on multi-criteria integrated additive-multiplicative utility function. Journal of civil engineering and management. 2014, Vol. 20, Iss. 4, pp. 590-599. ISSN 1392-3730. 
[2] BRETON, S.P., MOE, G. Status, plans and technologies for offshore wind turbines in Europe and North America. Renewable Energy. 2009, Vol. 34, Iss. 3, pp. 646-654. ISSN 0960-1481.

[3] CAVALLARO, F., CIRAOLO, L. A multicriteria approach to evaluate wind energy plants on an Italian island. Energy Policy. 2005, Vol. 33, Iss. 2, pp. 235-244. ISSN 0301-4215.

[4] FIEDLER, K., PELDSCHUS, F., ZAVADSKAS, E.K. Methoden der bautechnologischen Enschei dung. Wiss. Berichte der Technischen Hochschule Leipzig. 1986, pp. 17-56.

[5] GULBINSKAS, S. Wind energy development opportunities in the Baltic sea. In Conference Wind Energy Development and Prospects. 2009, June 15 , Vilnius.

[6] HWANG, C.L., YOON, K.S. Multiple Attribute Decision Making. Methods and Applications. Berlin, Heidelberg, New York: Springer-Verlag, 1981. 259 pp. ISBN 978-3-642-48318-9.

[7] ISHIZAKA, A., NEMERY, P. Multi-criteria decision analysis: methods and software. West Sussex: Wiley, 2013. 310 pp. ISBN 978-1-11997407-9.

[8] KILDIENE, S., ZAVADSKAS, E.K., TAMOŠAITIENE, J. Complex assessment model for advanced technology deployment. Journal of civil engineering and management. 2014, Vol. 20, Iss. 2, pp. 280-290. ISSN 1392-3730.

[9] LEE, A.H.I., CHEN, H.H., KANG, H.Y. Multicriteria decision making on strategic selection of wind farms. Renewable Energy. 2009, Vol. 34, Iss. 1, pp. 120-126. ISSN 0960-1481.

[10] LEUNG, D.Y.C., YANG, Y. Wind energy development and its environmental impact: A review. Renewable and Sustainable Energy Reviews. 2012, Vol. 16, Iss. 1, pp. 1031-1039. ISSN 1364-0321.

[11] Ministry of Energy of the Republic of Lithuania. National Energy Independence Strategy of the Republic of Lithuania. Vilnius, Nr. XI-2133, 2012. ISBN 978-609-95429-0-4.

[12] MARKEVIČIUS, A., KATINAS, V., MARČIUKAITIS, M. Wind energy development policy and prospects in Lithuania. Energy Policy. 2007, Vol. 35, Iss. 10, pp. 4893-4901. ISSN 0301-4215.

[13] MILLER, G.T., SPOOLMAN, S.E. Living in the environment. Principles, Connections, and Solutions. 16th ed. Cengage Learning, 2009. 828 p. ISBN 978-0495556718.

[14] MURPHY, J., LYNCH, K., SERRI, L., AIRDOLDI, D., LOPES, M. Site Selection Analysis for Offshore Combined Resource Projects in
Europe. In Results of the FP7 ORECCA Project Work Package 2. ORECCA, 28th October, 2011. 117 p. Available also from: http://www.orecca.eu/c/ document_library/get_file?uuid=1fff9401-0348463e-8a6f-62dfd21 bdfc8\&groupld=10129.

[15] OZERDEM, B., OZER, S., TOSUN, M. Feasibility study of wind farms: A case study for Izmir, Turkey. Journal of Wind Engineering and Industrial Aerodynamics. 2006, Vol. 94, Iss. 10, pp. 725-743. ISSN 0167-6105.

[16] PAELINCK, J. Qualitative multiple criteria analysis: on application to airport location. Netherlands economic institute: paper prepared for second Tokyo environmental conference. $24 \mathrm{p}$. Rotterdam, August, 1976.

[17] Project POWER [online]. Baltic offshore energy cluster, 2008 [cit. 2014-02-10]. Available from: http://www.bosec.lt/eco/eco_lt.html.

[18] SAATY, T.L. The Analytic Hierarchy Process: Planning, Priority Setting, Resource Allocation. Mcgraw-Hill. 1980. 287 p. ISBN 978-0070543713. [19] SAATY, T.L., VARGAS, L.G. Models, methods, concepts and applications of the analytic hierarchy process. Berlin, Heidelberg, London: Springer, 2012. 353 p. ISBN 978-1-4614-3597-6. [20] TALINLI, I., TOPUZ, E., AYDIN, E., KABAKCI, S. [Chap.] 10, A Holistic Approach for Wind Farm Site Selection by Using FAHP. In SUVIRE, O.G. (ed.). Wind Farm - Technical Regulations, Potential Estimation and Siting Assessment. 2011. 246 p. ISBN 978-953-307-483-2.

[21] The European wind energy association [online]. Winds energy basics 2014 [cit. 2014-0315]. Available from: www.ewea.org.

[22] The model for economical feasibility study of offshore wind power parks. Perspectives of Offshore Wind Energy development in marine areas of Lithuania, Poland and Russia, Lithuania. 2008. $30 \mathrm{p}$.

[23] TRIANTAPHYLLOU, E., MANN, S.H. Using the analytic hierarchy process for decision making in engineering applications: some challenges. International Journal of Industrial Engineering: Applications and Practice. 1995, Vol. 2, Iss. 1, pp. 35-44. ISSN 1072-4761.

[24] TURSKIS, Z. Multi-attribute contractors ranking method by applying ordering of feasible alternatives of solutions in terms of preferability technique. Baltic Journal on Sustainability. 2008 , Vol. 14, Iss. 2, pp. 224-239. ISSN 2029-4913.

[25] TURSKIS, Z., ZAVADSKAS, E.K. A new fuzzy additive ratio assessment method (ARAS-F). Case study: The analysis of fuzzy multiple criteria 


\section{Ekonomika a management}

in order to select the logistic centers location. Transport. 2010, Vol. 25, Iss. 4, pp. 423-432. ISSN 1648-4142.

[26] VAGIONA, D.G., KARANIKOLAS, N.M. A multicriteria approach to evaluate offshore wind farms siting in Greece. Global NEST Journal. 2012, Vol. 14, Iss. 2, pp. 235-243. ISSN 1790-7632.

[27] WELCH, J., VENKATESWARAN, A. The Dual Sustainability of Wind Energy. Renewable and Sustainable Energy Reviews. 2009, Vol. 13, Iss. 5, pp. 1121-1126. ISSN 1364-0321.

[28] WINDPOWER, DVORAK, P. World Wind Energy Assn sees 1,900 GW by 2020 [online]. Windpower, Engineering and development, 2010-09-22 [cit. 2014-03-10]. Available from: http://www.windpowerengineering.com/policy/ world-wind-energy-assn-sees-1900-gw-by-2020/. [29] ZAMFIROIU, C.E. Selection of the investment projects "Wind farms in Romania“ by using multicriteria methods for sustainable development. 2011. Available also from: http://www.dafi.ase.ro/ revista/5/Zamfiroiu\%20Carmen\%20Elena.pdf.

[30] ZAVADSKAS, E.K., PELDSCHUS, F., KAKLAUSKAS, A. Multiple criteria evaluation of projects in construction. Vilnius: Technika, 1994. 226 p. ISBN 9986050464.

[31] ZAVADSKAS, E.K., TURSKIS, Z., TAMOSAITIENE, J. Selection of construction enterprises management strategy based on the SWOT and multi-criteria analysis. Archives of Civil and Mechanical Engineering. 2011, Vol. 11, Iss. 4, pp. 1063-1082. ISSN 1644-9665.
Vygantas Bagočius

Vilnius Gediminas Technical University Klaipeda University

Faculty of Civil Engineering

Department of Construction Technology and Management vygantas.bagocius@vgtu.It

prof. Edmundas Kazimieras Zavadskas

Vilnius Gediminas Technical University

Faculty of Civil Engineering

Department of Construction Technology and Management

Edmundas.Zavadskas@vgtu.It

prof. Zenonas Turskis

Vilnius Gediminas Technical University

Faculty of Civil Engineering

Department of Construction Technology and Management Zenonas.Turskis@vgtu.It 


\section{Abstract}

\section{SEQUENCE DETERMINING OF CONSTRUCTION OF THE OFFSHORE WIND FARM CONSTRUCTION APPLYING PERMUTATION METHOD}

\section{Vygantas Bagočius, Edmundas Kazimieras Zavadskas, Zenonas Turskis}

Ranking of work or feasible investments is one of high-importance keys for successful economic development. The share of renewable energy sources in the Lithuanian primary energy supply is on the lowest among EU. Only bio fuel, hydro and wind power can be considered as potential renewable energy sources in Lithuania at present time. Wind energy generation mature technology and comparatively low cost make it promising as an important primary energy source in the nearest future.

The aim of this paper is to determine the sequence for the wind turbine construction in the waters of Lithuania. The key criteria set for was determined for the problem solution: area of the territory, water depth, distance to shore, average wind velocity, max power on the area, amount of energy per year, investments and CO2. AHP method is used to estimate criteria weights. The problem was solved applying multi-attribute permutation method. This method allows dealing with qualitative and quantitative as well as with linguistic (verbal) data.

Key Words: Offshore wind turbine, multi-criteria decision-making, permutation method, AHP method.

JEL Classification: G34, M12.

DOI: 10.15240/tul/001/2014-3-005 